\title{
Changes in Cholinesterase Activity, Nerve Conduction Velocity, and Clinical Signs and Symptoms in Termite Control Operators Exposed to Chlorpyrifos
}

\author{
Masahiro Gotoh ${ }^{1}$, Isao Saito ${ }^{2}$, Jian $\mathrm{HuAnG}^{3}$, Yukio Fukaya ${ }^{4}$, Tadao Matsumoto 5 , \\ Naomi Hisanaga ${ }^{6}$, Eiji Shibata ${ }^{7}$, Gaku Ichihara ${ }^{8}$, Michihiro KamiJima ${ }^{8}$ and \\ Yasuhiro TAKEUCHI ${ }^{8}$ \\ 'Asahi Rosai Hospital, ${ }^{2}$ Aichi Prefectural Institute of Public Health, ${ }^{3}$ Bayer U.S.A., \\ ${ }^{4}$ Aichi Bunkyo Women's College, ${ }^{5}$ Konan Health Center, Aichi Prefecture, \\ ${ }^{6}$ National Institute of Industrial Health, ${ }^{7}$ School of Health Sciences, Nagoya University, \\ ${ }^{8}$ Department of Occupational and Environmental Health, Nagoya University Graduate School of Medicine
}

\begin{abstract}
Changes in Cholinesterase Activity, Nerve Conduction Velocity, and Clinical Signs and Symptoms in Termite Control Operators Exposed to Chlorpyrifos: Masahiro Gотон, et al. Asahi Rosai Hospital-We have surveyed periodical medical examinations for pest and termite control operators $(n=64)$ exposed to chlorpyrifos and other organophosphate pesticides. Distribution of serum butyrylcholinesterase (BUChE) activities of all workers ranged 0.01-1.18 $(\Delta \mathrm{pH})$. Serum BuChE activities in 6 workers in one termite control company were severely depressed and ranged from 0.01 to $0.21 \Delta \mathrm{pH}$. Erythrocyte acetylcholinesterase (AChE) activities in 3 workers were lower than the normal range. Erythrocyte AChE activities and serum BuChE acitivities in chlorpyrifos sprayers were significantly correlated $(r=0.720)$. In other clinical signs, blood urine nitrogen (BUN) in 4 workers and white blood cell (WBC) counts in 4 workers were abnormal. Sensory nerve conduction velocities in the sural nerve of all 6 workers were significantly reduced to $18.8-26.6 \mathrm{~m} / \mathrm{s}$ in the left leg and $19.2-27.2 \mathrm{~m} / \mathrm{s}$ in the right leg. In the results of ophthalmic examinations, accommodation time (both eyes) in 4 workers extended over the normal range and electroretinography (ERG) in 2 workers showed abnormal ERG including disappearance of oscillatory potential. Chlorpyrifos residue in blood in 4 operators whose serum BuChE activities ranged from 0.01 to 0.03 $\Delta \mathrm{pH}$ were detected in the range $2-8 \mathrm{ng} / \mathrm{ml}$. They had sprayed chlorpyrifos daily for $5 \mathrm{~d}$ before every blood sampling. It is suggested that serum BuChE activity and sensory nerve conduction velocity are sensitive
\end{abstract}

Received Dec 4, 2000; Accepted Feb 28, 2001

Correspondence to: M. Gotoh, Asahi Rosai Hospital, 6I Kita, Hirakocho, Owariasahi-shi, 488-8585 Japan indicators to evaluate the effects of chlorpyrifos exposure, and may be used effectively to monitor exposure and the effects of chlorpyrifos on health. (J Occup Health 2001; 43: 157-164)

Key words: Chlorpyrifos, Exposure, Termite control operators, Blood, Cholinesterase, Peripheral nerve conduction velocity

Chlorpyrifos ( $O, O$-diethyl 0 -3,5,6-trichloro-2-pyridylphosphorothioate, chlorpyrifos ethyl, Dursban) is a chlorinated organophosphate insecticide that is widely used for pest control throughout the world. Approximately 21 to 24 million pounds are used annually in the U.S., of which approximately 11 million pounds are applied in non-agricultural settings. Seventy percent of the urban chlorpyrifos is estimated to be used for termite control ${ }^{11}$. Previously, chlordane, one of the organochlorine insecticides, had been used for termite control in Japan, but it was prohibited for use in termite control in 1986 by reason of the environmental pollution and bioaccumulation ${ }^{2,3)}$. Chlorpyrifos began to be used mainly for termite control instead of chlordane. After the switch to chlorpyrifos, there have been some reports about exposure to chlorpyrifos, inhibition of cholinesterase (ChE) activity, and subjective symptoms among termite control operators (TCOs) ${ }^{4-9}$.

The U.S. Environmental Protection Agency (EPA) recently started to evaluate pesticide safety in the light of potential aggregate exposures by both the non-dietary and dietary routes in accordance with the Food Quality Protection Act of 19961). Davis reported greater health risks to children caused by exposure to indoor spraying of chlorpyrifos ${ }^{10)}$. Other researchers have reported 
potential health risks such as birth defects ${ }^{11)}$ and immunologic abnormalities ${ }^{12}$. The U.S. EPA and the manufacturer of chlorpyrifos have agreed to halt its manufacture for nearly all residential use by December 2000. Phase-out of its use for termite control in buildings other than homes or areas where children could be exposed is slated for the end of 2001 , and phase-out of termiticide use on new construction by the end of 2004 unless new information becomes available which shows that this use could safely continue ${ }^{(3)}$. Now in Japan, there is similar reaction to the use of chlorpyrifos for termite control.

Assessing human health in TCOs is very important in evaluating chlorpyrifos exposure, because they were exposed occupationally to a large amount of chlorpyrifos, and these data could be extrapolated to assess the health hazards at lower exposure levels, but there are few reports about occupational exposure and the impact on the health of TCOs from chlorpyrifos ${ }^{4-91}$. Therefore, we surveyed subjective symptoms, serum and erythrocyte ChE activities, insectiside spraying conditions, residual chlorpyrifos blood levels, and also conducted biochemical, neurological and ophthalmic examinations among the pest and termite control operators.

\section{Subjects and Methods}

\section{Subjects}

We retrospectively surveyed the results of medical examinations of 64 male termite and pest control operators (aged 21-60 yr) in 9 companies, who have been annually health-checked at Asahi Rosai Hospital. The subjects included 12 termite control operators in 2 companies who sprayed chlorpyrifos; 39 pest and termite control operators in 5 firms who sprayed chlorpyrifos and pyridaphenthion for termite control, and fenitrothion (sumithion), dichlorvos, fenthion and chlorpyrifos methyl for pest control; and 13 pest control operators in 2 companies (Table 1).

\section{Questionnaire}

In this study, we used a self-administerated questionnaire that contained 90 questions about subjective symptoms and the conditions for spraying pesticides which covered the annual amounts of each type of pesticide formulation, spraying days per month, and a weekly record of spraying time before the medical examination. The questionnaire on subjective symptoms requested information on acute or sub-acute cholinergic symptoms and effects on the nervous system.

\section{Health examination}

Physical examinations, hematological parameters, and serum biochemical examinations were conducted.

\section{Determination of cholinesterase activities}

We collected blood samples from subjects in the morning and measured serum BuChE activities by the $\triangle \mathrm{pH}$ method ${ }^{14)}$ and erythrocyte $\mathrm{AChE}$ activities by the DTNB method ${ }^{15}$.

Determination of organophosphorus pesticide residues in the blood

Blood was mixed with water and extracted twice with acetone-hexane (1:9). The extract was dried with anhydride sodium sulfate and evaporated in vacuo. The residue was dissolved in acetone and analyzed in a gas chromatograph (GC) equipped with a flame photometric detector (P mode). GC condition: column 2\% OV101/ Chromosorb W HP 100/120 mesh, $2 \mathrm{~mm}$ id $\times 1 \mathrm{~m}$. Carrier gas: nitrogen, $10 \mathrm{ml} / \mathrm{min}$; column temperature: $150^{\circ} \mathrm{C}$ (for $1 \mathrm{~min}) \rightarrow 6^{\circ} \mathrm{C} / \mathrm{min} \rightarrow 240^{\circ} \mathrm{C}$.

\section{Neurological and ophthalmological examinations}

Six termite control operators whose serum BuChE activities were severely depressed, were examined neurologically and ophthalmologically. The examinations included electroencephalography (EEG), peripheral nerve conduction velocity, and ophthalmic testing of visual acuity, color sensation, critical flicker frequency, accommodation time, and electroretinography (ERG).

\section{Results}

Distribution of serum BuChE activities and annual amounts of insecticides sprayed by each pest and termite control company are shown in Table 1. Workers in companies $\mathrm{A}$ and $\mathrm{B}$ are professional termite control operators (TCOs). Those in companies $\mathrm{C}$ to $\mathrm{G}$ are pest and termite control operators. Workers in company $\mathrm{A}$ sprayed great amounts of $40 \%$ emulsion 298 liters/yr and $1 \%$ oil formulation 1304 liters/yr of chlorpyrifos for termite control annually. Serum BuChE activities of all workers ranged $0.01-1.18(\Delta \mathrm{pH})$. The levels of 14 workers in 4 companies $(\mathrm{A}, \mathrm{B}, \mathrm{C}, \mathrm{D})$ were below 0.5 $\Delta \mathrm{pH}$, which is below the normal range.

A comparison of subjective symptoms in the workers whose serum BuChE activities were above or below 0.5 $\Delta \mathrm{pH}$ is shown in Table 2. A high incidence of eye irritation, coughing and sneezing during spraying, severe fatigue after spraying were observed in the workers with BuChE activities below $0.5 \Delta \mathrm{pH}$, but the incidence of these symptoms was not statistically significant in comparison with that in the group whose serum $\mathrm{ChE}$ activity was found to be $0.5 \Delta \mathrm{pH}$ or over by chi-square test.

The relationship between serum and erythrocyte ChE activities in all pest and termite control operators is shown in Fig. 1. The coefficient of correlation between them was 0.419 . To clarify the inhibition of ChE activities due to chlorpyrifos exposure, further analysis was made 
Table 1. Annual amounts of pesticides sprayed by each operator and the range of serum butyrylcholinesterase (BuChE) activities in workers in 9 companies

\begin{tabular}{|c|c|c|c|c|c|c|c|c|c|c|c|}
\hline Company & $\begin{array}{c}\text { No. of } \\
\text { operatorss }\end{array}$ & $\begin{array}{c}40 \% \mathrm{CP} \\
\mathrm{E}\end{array}$ & $\begin{array}{c}1 \% \mathrm{CP} \\
0\end{array}$ & $\begin{array}{c}40 \% \mathrm{P} \\
\mathrm{E}\end{array}$ & $\begin{array}{c}1 \% \mathrm{P} \\
\mathrm{O}\end{array}$ & $\begin{array}{c}5 \% \mathrm{~F}- \\
2 \% \mathrm{~V} \\
\mathrm{E}\end{array}$ & $\begin{array}{c}10 \% \mathrm{CPM} \\
\mathrm{E}\end{array}$ & $\begin{array}{l}5 \% \mathrm{~B}- \\
2 \% \mathrm{~V} \\
\mathrm{E}\end{array}$ & $\begin{array}{c}5 \% \mathrm{CPM}- \\
2 \% \mathrm{~V} \\
\text { E }\end{array}$ & $\begin{array}{c}5 \% \mathrm{~B} \\
\mathrm{E}\end{array}$ & $\begin{array}{c}\text { Serum BuChE } \\
\text { activities }(\Delta \mathrm{pH}) \\
\text { (mean value) }\end{array}$ \\
\hline A & 9 & 298 & 1304 & 0 & 0 & 0 & 0 & 0 & 0 & 0 & $0.01-0.66(0.18)$ \\
\hline B & 3 & 59 & 0 & 0 & 0 & 0 & 0 & 0 & 0 & 0 & $0.31-0.67(0.43)$ \\
\hline $\mathrm{C}$ & 3 & 0 & 0 & 333 & 117 & 127 & 0 & 0 & 0 & 0 & $0.39-0.86(0.58)$ \\
\hline $\mathrm{D}$ & 7 & 22 & 0 & 0 & 0 & 0 & 0 & 0 & 180 & 0 & $0.38-1.05(0.74)$ \\
\hline $\mathrm{E}$ & 18 & 6 & 13 & 0 & 0 & 117 & 0.7 & 0 & 0.3 & 0 & $0.54-1.03(0.76)$ \\
\hline $\mathrm{F}$ & 6 & 8 & 4 & 0 & 0 & 22 & 0 & 0 & 74 & 0 & $0.59-1.12(0.82)$ \\
\hline $\mathrm{G}$ & 5 & 1 & 4 & 80 & 156 & 23 & 0 & 24 & 0 & 0 & $0.71-0.89(0.80)$ \\
\hline $\mathrm{H}$ & 10 & 0 & 0 & 0 & 0 & 14 & 206 & 24 & 2 & 22 & $0.65-1.18(0.83)$ \\
\hline I & 3 & 0 & 0 & 0 & 0 & 3 & 26 & 0 & 0 & 0 & $0.76-0.90(0.82)$ \\
\hline
\end{tabular}

CP, chlorpyrifos; P, pyridaphenthion; F, fenitrothion; V, dichlorvos; CPM, chlorpyrifos methyl; B, fenthion. Formulation type: E, emulsion; $\mathrm{O}$, oil (unit: liters).

Table 2. Comparison of subjective symptoms during organophosphate spraying in workers whose serum butyrylcholinesterase were above or below $0.5 \Delta \mathrm{pH}$

\begin{tabular}{lcc}
\hline \multicolumn{1}{c}{ Symptoms } & $\begin{array}{c}\Delta \mathrm{pH}<0.5 \\
\mathrm{n}=13 \%\end{array}$ & $\begin{array}{c}\Delta \mathrm{pH} \geqq 0.5 \\
\mathrm{n}=50\end{array}$ \\
\cline { 2 - 3 } Headache & $30.7 \%$ & $32.0 \%$ \\
Dull headache & $30.7 \%$ & $16.0 \%$ \\
Nasal discharge & $46.2 \%$ & $36.0 \%$ \\
Discomfort in the throat & $30.7 \%$ & $46.0 \%$ \\
Cough and sneeze & $53.8 \%$ & $50.0 \%$ \\
Eye irritation & $76.9 \%$ & $52.0 \%$ \\
Lassitude & $46.2 \%$ & $34.0 \%$ \\
Ill feeling during spraying & $46.2 \%$ & $40.0 \%$ \\
Severe fatigue after spraying & $61.5 \%$ & $46.0 \%$ \\
\hline
\end{tabular}

*One worker (below $0.5 \Delta \mathrm{pH}$ ) was omitted by incomplete replies to the questionnaire.

on the termite control operators who sprayed only chlorpyrifos within the last one month $(n=16)$. The coefficient of correlation increased to 0.720. In Fig. 2, linear regression analysis was performed to determine the degree of linear association between serum BuChE and erythrocyte $\mathrm{AChE}$. Log transformed serum $\mathrm{BuChE}$ was closely associated with erythrocyte $\mathrm{AChE}\left(\mathbf{R}^{2}=0.791\right.$, $\mathrm{p}<0.01$ ). In 3 workers whose serum $\mathrm{BuChE}$ activities were below $0.1 \Delta \mathrm{pH}$, the erythrocyte $\mathrm{AChE}$ activities were depressed to below 1.5 .

In the group whose serum BuChE activities were severely depressed, we chose six workers engaged in one termite control company for detailed medical examinations. Table 3 shows the spraying conditions and sprayer characteristics. The mean age of the sprayers was $25.8 \mathrm{yr}$, and the current job duration was $2-3 \mathrm{yr}$.

They had sprayed great amounts of chlorpyrifos for termite control annually. Their mean working $\mathrm{d} /$ month and mean working $\mathrm{h} / \mathrm{d}$ were 22.0 and 2.7 , respectively. Their job was to spray chlorpyrifos every day in the busy season.

Table 4 gives the results of blood tests on 6 workers. Their serum BuChE activities ranged from 0.01 to 0.21 $\triangle \mathrm{pH}$. Erythrocyte AChE activities in 3 workers were lower than the normal range $(1.5 \leqq)$. Blood urine nitrogen (BUN) of 4 workers and the white blood cell count (WBC) in the blood of 4 workers were abnormal. Other blood biochemical data were within normal range. Chlorpyrifos residue in blood was $2-8 \mathrm{ng} / \mathrm{ml}$ in 4 operators whose serum BuChE activities ranged from 0.01 to $0.03 \Delta \mathrm{pH}$. They had sprayed only chlorpyrifos daily for 5 days before every blood sampling.

Table 5 shows the results of electroencephalography (EEG) and peripheral nerve conduction velocity (motor conduction velocity and sensory conduction velocity). All EEGs were within normal limits. Motor nerve conduction velocities were nearly all within the normal range except those in the tibial nerve of two workers. The sensory nerve conduction velocity in the sural nerve was significantly reduced to $18.8-26.6 \mathrm{~m} / \mathrm{s}$ in the left leg and $19.2-27.2 \mathrm{~m} / \mathrm{s}$ in the right leg in all 6 workers (normal range: $34-49 \mathrm{~m} / \mathrm{s}$ ).

The results of ophthalmic examinations are shown in Table 6. Visual acuity, color sensation and critical flicker frequency were within the normal range, but accommodation time (both eyes) in 4 workers was beyond normal (under $4 \mathrm{sec}$ ), and electroretinography (ERG) in 2 workers showed abnormal ERG, that is disappearance of oscillatory potential. 


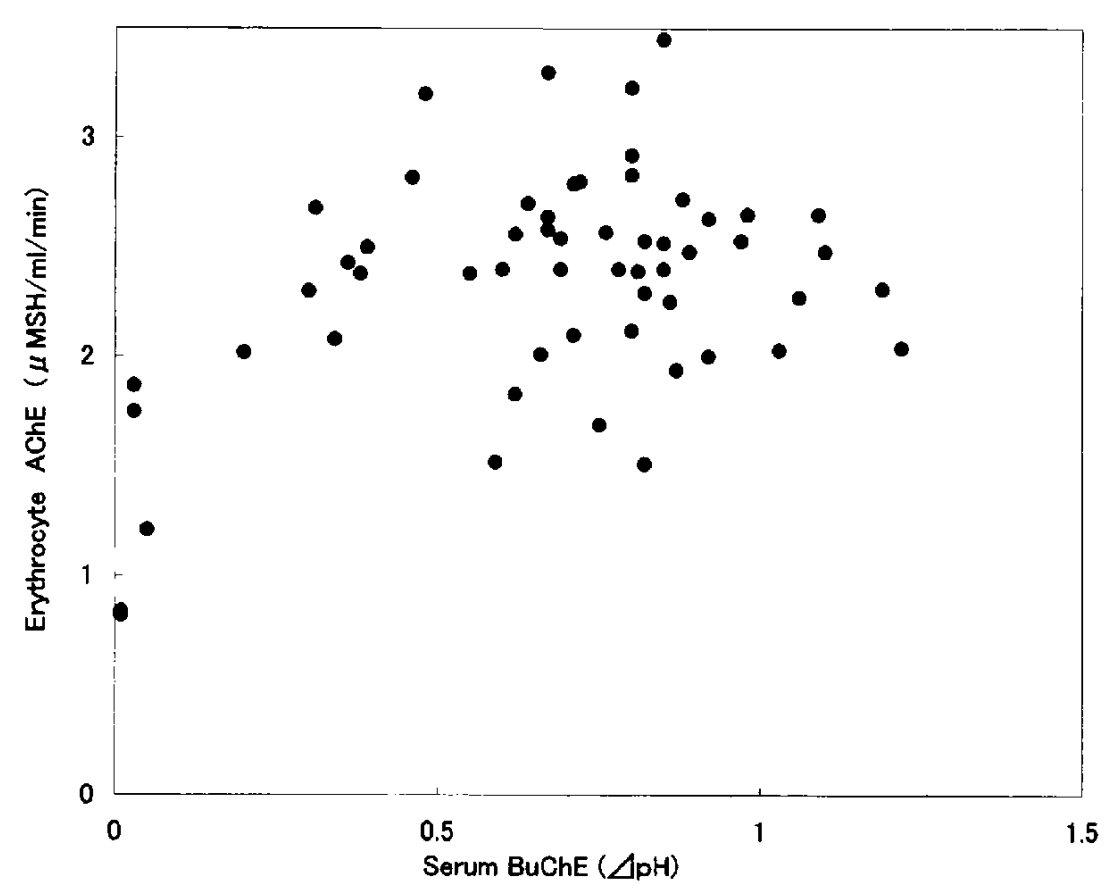

Fig. 1. Relationship between serum and crythrocyte cholinesterase activities ( $n=64)$. BuChE, butyrylcholinesterase; AChE, acetylcholinesterase.

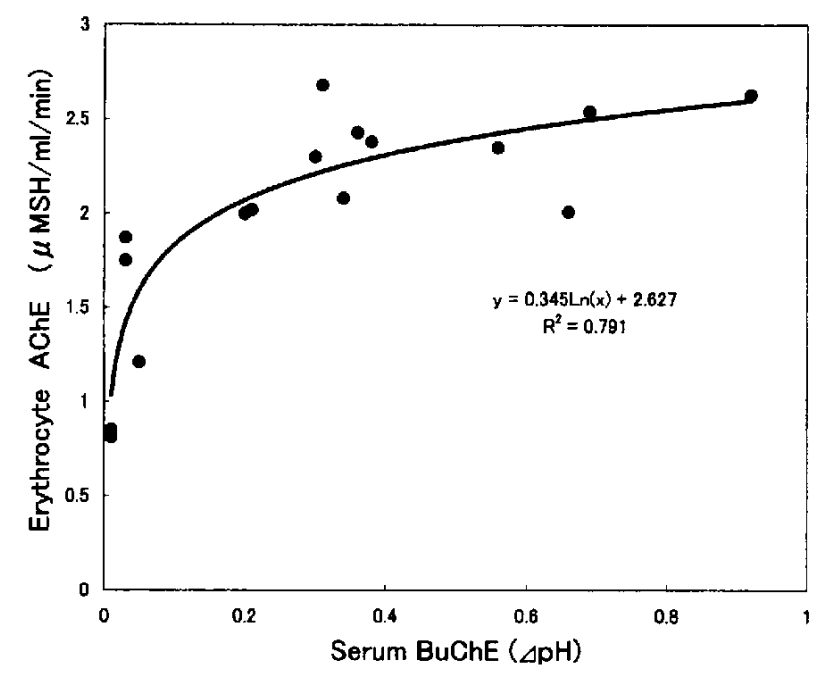

Fig. 2. Relationship between serum and erythrocyte cholinesterase activities in termite control operators who had sprayed chlorpyrifos within the last month $(\mathbf{n}=16)$. BuChE, butyrylcholinesterase; AChE, acetylcholinesterase.

\section{Discussion}

When the switch was first made from chlordane to chlorpyrifos for termite control by means of the same application manner and method, some reports were published on the depression of serum or plasma ChE levels in termite control operators due to exposure to chlorpyrifos ${ }^{6.7 .9)}$. In our survey, serum BuChE activities were severely depressed to below $0.21 \Delta \mathrm{pH}$ in six termite control operators, who worked for the same company and sprayed great amounts of chlorpyrifos. Three of these workers show depression of erythrocyte AChE activity. We supposed this was due to the severe exposure to chlorpyrifos from applying it in the same way as chlordane, which did not inhibit AChE activity and was less acutely toxic than chlorpyrifos. The risk potential of chlorpyrifos application therefore paradoxically increased for TCOs compared to chlordane application ${ }^{16}$.

Although the workers with depressed serum BuChE activities had such symptoms as eye irritation, coughing and sneezing during spraying, and severe fatigue after spraying, they had no severe acute symptoms. Jitsunari et al. and Ueda et al. also reported that the TCOs with the lowest serum cholinesterase activities exhibited no subjective symptoms at the time ${ }^{8,9)}$.

Asakawa et al ${ }^{6)}$ reported that the ambient concentration of chlorpyrifos in the breathing zone was about 10 times higher $\left(1.7-2.3 \mathrm{mg} / \mathrm{m}^{3}\right)$ in case of the application of $1 \%$ emulsion under the floor of a residence than the thresholdlimit value $\left(0.2 \mathrm{mg} / \mathrm{m}^{3}\right)$ proposed by the $\mathrm{ACGIH}{ }^{17)}$. The lowest level of serum cholinesterase sprayed during the busy season for termite control was less than $10 \%$ of the pre-season values. Chlorpyrifos application induced a severe depression in the serum $\mathrm{ChE}$ of sprayers, but no marked subjective or objective abnormalities were found. 
Table 3. Characteristics and spraying conditions of 6 termite control operators

\begin{tabular}{lrrrrrr}
\hline \multicolumn{1}{c}{ Operator } & A & B & C & D & E & F \\
\cline { 2 - 6 } Age & 33 & 25 & 26 & 29 & 21 & 21 \\
Weight $(\mathrm{kg})$ & 68 & 76 & 65 & 68 & 45 & 58 \\
Height (cm) & 176 & 171 & 175 & 173 & 158 & 165 \\
Current job duration (yr) & 3 & 3 & 3 & 3 & 2 & 2 \\
Annual spraying amounts (L) & & & & & & \\
$\quad 40 \%$ Chlorpyrifos emulsion & 393 & 344 & 407 & 267 & 341 & 375 \\
1\% Chlorpyrifos oil & 1080 & 1466 & 1786 & 1600 & 1605 & 1142 \\
Mean spraying d/month & 23 & 23 & 23 & 18 & 22 & 23 \\
Mean spraying h/d & 3.2 & 3.2 & 3.2 & 3.2 & 1.9 & 1.5 \\
\hline
\end{tabular}

They had sprayed chlorpyrifos for every $5 \mathrm{~d}$ before their blood sampling.

Table 4. Blood and serum examination of 6 termite control operators

\begin{tabular}{|c|c|c|c|c|c|c|c|}
\hline Operator & $\mathrm{A}$ & B & $\mathrm{C}$ & $\mathrm{D}$ & $\mathbf{E}$ & $\mathrm{F}$ & Normal range \\
\hline Total protein $(\mathrm{g} / \mathrm{d} l)$ & 7.7 & 7.5 & 7.1 & 7.3 & 7.3 & 7.4 & $6.2-8.0$ \\
\hline $\mathrm{A} / \mathrm{G}$ & 1.75 & 1.68 & 1.73 & 1.61 & 1.70 & 1.64 & $1.2-1.8$ \\
\hline ZTT (U) & $3.2 *$ & $3.9^{*}$ & 5.5 & 4.8 & 5.7 & 7.0 & $4-12$ \\
\hline Total bilirubin $(\mathrm{mg} / \mathrm{d} l)$ & 0.5 & 0.7 & 0.6 & 0.4 & 0.8 & 0.7 & $0.1-1.0$ \\
\hline $\operatorname{ALP}(\mathrm{U} / l)$ & 205 & 182 & 172 & 152 & 132 & 173 & $100-280$ \\
\hline $\mathrm{LAP}(\mathrm{U} / l)$ & $67^{*}$ & $74 *$ & 38 & 40 & 46 & 48 & $20-60$ \\
\hline $\mathrm{LDH}(\mathrm{U} / l)$ & 368 & 194 & 273 & 282 & 260 & 248 & $230-460$ \\
\hline AST (GOT) $(\mathrm{U} / l)$ & 19 & 21 & 12 & 13 & 9 & 13 & $7-38$ \\
\hline $\operatorname{ALT}(\mathrm{GPT})(\mathrm{U} / l)$ & 14 & 27 & 7 & 11 & 5 & 16 & $8-40$ \\
\hline$\gamma \mathrm{GTP}(\mathrm{U} / l)$ & $87^{*}$ & $83^{*}$ & 9 & 21 & 11 & 20 & $11-51$ \\
\hline Blood sugar $(\mathbf{m g} / \mathrm{d} l)$ & $111 *$ & 90 & 92 & 96 & 84 & 96 & $70-100$ \\
\hline Total cholesterol $(\mathrm{mg} / \mathrm{d} /)$ & 203 & $242 *$ & 127 & 209 & 150 & 159 & $120-230$ \\
\hline Triglyceride $(\mathrm{mg} / \mathrm{d} l)$ & $158^{*}$ & $371^{*}$ & 60 & 79 & 65 & 130 & $36-130$ \\
\hline $\mathrm{BUN}(\mathrm{mg} / \mathrm{d} l)$ & $21.3 *$ & $22.2^{*}$ & 17.5 & $22.6 *$ & 18.3 & $24.7 *$ & $8-20$ \\
\hline $\mathrm{Cr}(\mathrm{mg} / \mathrm{d} l)$ & 0.8 & 1.0 & 0.8 & 0.9 & 0.7 & 0.9 & $0.7-1.7$ \\
\hline $\mathrm{UA}(\mathrm{mg} / \mathrm{d} l)$ & 7.6 & $10.0^{*}$ & 4.6 & 6.3 & 5.4 & 5.6 & $2.5-7.5$ \\
\hline WBC $\left(/ \mathrm{mm}^{3}\right)$ & $10300^{*}$ & 5800 & 7000 & $4400 *$ & $9900^{*}$ & $4000^{*}$ & $5000-8000$ \\
\hline $\mathrm{RBC}\left(\times 10^{4} / \mathrm{mm}^{3}\right)$ & 495 & 497 & 447 & 421 & 482 & 470 & $410-530$ \\
\hline $\mathrm{Hb}(\mathrm{g} / \mathrm{d} l)$ & 16.7 & 17.5 & 16.4 & 15.7 & 15.8 & 16.1 & $14-18$ \\
\hline $\mathrm{Ht}(\%)$ & 44.5 & 45.5 & 44.0 & 42.0 & 43.0 & 42.5 & $39-52$ \\
\hline Serum BuChE $(\Delta \mathrm{pH})$ & $0.21 *$ & $0.03^{*}$ & $0.01 *$ & $0.03^{*}$ & $0.01 *$ & $0.05^{*}$ & $0.5-1.2$ \\
\hline $\begin{array}{l}\text { Erythrocyte AChE } \\
(\mu \mathrm{MSH} / \mathrm{m} l / \mathrm{min})\end{array}$ & 1.99 & 1.75 & $0.84 *$ & 1.87 & $0.83^{*}$ & $1.21 *$ & $1.5-$ \\
\hline $\begin{array}{l}\text { Chlorpyrifos concentration } \\
\text { in blood }(\mathrm{ng} / \mathrm{ml})\end{array}$ & nd & 4 & 8 & 2 & 2 & nd & \\
\hline
\end{tabular}

nd: not detected, *: out of normal range.

Nolan et al. reported that human volunteers who were given a single $0.5 \mathrm{mg} / \mathrm{kg}$ p.o. of chlorpyrifos were depressed to $15 \%$ of the predose level of serum ChE, and that the erythrocyte $\mathrm{AChE}$ level was not changed ${ }^{18)}$. Griffin et al. administered $1 \mathrm{mg}$ of chlorpyrifos to 5 human volunteers ${ }^{19}$, and the blood plasma and erythrocyte
ChE activity did not fall significantly during the regimen. ACGIH indicated that $70 \%$ of the normal erythrocyte AChE level is the critical point ${ }^{17}$, but chlorpyrifos, diazinon, malathion and dichlorvos preferentially inhibit plasma $\mathrm{ChE}$ in man rather than erythrocyte $\mathrm{AChE}^{21}$.

In our study, serum BuChE in 6 workers was severely 
Table 5. Electroencephalogram (EEG) and peripheral nerve conduction velocities of 6 termite control operators

\begin{tabular}{|c|c|c|c|c|c|c|c|c|}
\hline \multicolumn{2}{|c|}{ Operator } & A & B & $\mathrm{C}$ & $\mathrm{D}$ & $\mathrm{E}$ & $\mathrm{F}$ & Normal range \\
\hline \multicolumn{2}{|c|}{ Electroencephalogram (EEG) } & normal & normal & normal & normal & normal & normal & \\
\hline \multicolumn{9}{|c|}{ Peripheral nerve conduction velocity $(\mathrm{m} / \mathrm{s})$} \\
\hline \multicolumn{9}{|c|}{ Motor nerves (MCV) } \\
\hline \multirow[t]{2}{*}{ Median n. } & (left) & 67.6 & 70.0 & 62.5 & 64.0 & 65.5 & 66.6 & $47-60$ \\
\hline & (right) & 51.4 & 57.7 & 58.1 & 54.8 & 55.6 & 59.1 & $47-60$ \\
\hline \multirow[t]{2}{*}{ Ulnar n. } & (left) & 74.3 & 61.6 & 64.8 & 63.1 & 63.8 & 62.3 & $49-68$ \\
\hline & (right) & 59.2 & 66.6 & 75.8 & 61.8 & 63.8 & 60.2 & $49-68$ \\
\hline \multirow[t]{2}{*}{ Tibial n. } & (left) & $38.1^{*}$ & $40.6^{*}$ & 45.4 & 45.1 & 52.3 & 47.3 & $41-61$ \\
\hline & (right) & 44.8 & 45.7 & 45.9 & 49.3 & 53.0 & 50.0 & $41-61$ \\
\hline \multirow[t]{2}{*}{ Peroneal n. } & (left) & 51.2 & 47.3 & 52.7 & 47.9 & 54.8 & 48.6 & $43-62$ \\
\hline & (right) & 49.3 & 51.4 & 51.0 & 51.3 & 51.6 & 56.0 & $43-62$ \\
\hline \multicolumn{9}{|c|}{ Sensory nerves (SCV) } \\
\hline \multirow[t]{2}{*}{ Median n. } & (left) & 72.7 & 68.0 & 67.9 & 66.1 & 63.2 & 69.6 & $55-74$ \\
\hline & (right) & 63.4 & 65.0 & 64.0 & 58.0 & 69.5 & 64.6 & $55-74$ \\
\hline \multirow[t]{2}{*}{ Ulnar $n$. } & (left) & 85.2 & 70.3 & 70.5 & 66.6 & 74.1 & 70.6 & $54-74$ \\
\hline & (right) & 80.3 & 69.5 & 75.8 & 63.5 & 77.5 & 69.1 & $54-74$ \\
\hline \multirow[t]{2}{*}{ Sural n. } & (left) & $21.1^{*}$ & $23.2 *$ & $18.8^{*}$ & $26.6 *$ & $22.5^{\text {* }}$ & $24.1^{*}$ & $34-49$ \\
\hline & (right) & $21.5^{*}$ & $19.2^{*}$ & $21.3^{*}$ & $24.2^{*}$ & $27.2^{*}$ & $22.8^{*}$ & $34-49$ \\
\hline
\end{tabular}

*: below the normal range.

Table 6. Ophthalmic examinations of 6 termite control operators

\begin{tabular}{|c|c|c|c|c|c|c|c|c|}
\hline Operator & & A & B & $\mathrm{C}$ & $\mathrm{D}$ & $\mathrm{E}$ & $\mathrm{F}$ & Normal range \\
\hline $\begin{array}{l}\text { Visual acuity } \\
\text { (corrrected) }\end{array}$ & (left) & 1.2 & $\begin{array}{c}0.5 \\
(1.2)\end{array}$ & $\begin{array}{l}0.05 \\
(1.5)\end{array}$ & 1.2 & $\begin{array}{c}0.2 \\
(1.2)\end{array}$ & $\begin{array}{c}0.2 \\
(1.2)\end{array}$ & \\
\hline & (right) & 1.5 & $\begin{array}{c}0.4 \\
(1.5)\end{array}$ & $\begin{array}{l}0.06 \\
(1.0)\end{array}$ & 1.0 & $\begin{array}{c}0.3 \\
(1.5)\end{array}$ & $\begin{array}{c}0.3 \\
(1.2)\end{array}$ & \\
\hline Color sensation & & normal & normal & normal & normal & normal & normal & \\
\hline Critical flicker frequency $(\mathrm{Hz})$ & $\begin{array}{l}\text { (left) } \\
\text { (right) }\end{array}$ & $\begin{array}{l}37 \\
36\end{array}$ & $\begin{array}{l}38 \\
35\end{array}$ & $\begin{array}{l}40 \\
39\end{array}$ & $\begin{array}{l}40 \\
39\end{array}$ & $\begin{array}{l}41 \\
40\end{array}$ & $\begin{array}{l}39 \\
41\end{array}$ & $\begin{array}{l}35- \\
35-\end{array}$ \\
\hline Accommodation time (sec) & $\begin{array}{l}\text { (left) } \\
\text { (right) }\end{array}$ & $\begin{array}{l}5.6^{*} \\
5.1^{*}\end{array}$ & $\begin{array}{c}5.0^{*} \\
4.0\end{array}$ & $\begin{array}{l}7.0^{*} \\
5.5^{*}\end{array}$ & $\begin{array}{l}3.2 \\
2.8\end{array}$ & $\begin{array}{l}3.1 \\
3.7\end{array}$ & $\begin{array}{c}4.5^{*} \\
4.0\end{array}$ & $\begin{array}{l}-4 \\
-4\end{array}$ \\
\hline Electroretinogram (ERG) & & normal & $\begin{array}{c}\text { OP } \\
\text { disappear }\end{array}$ & $\begin{array}{l}\text { OP } \\
\text { sappears }\end{array}$ & normal & normal & normal & \\
\hline
\end{tabular}

*: out of normal range. OP, oscillatory potential.

depressed ( $\leqq 0.21 \Delta \mathrm{pH}$ ). Among them, three workers with lower $0.1 \mathrm{ApH}$ serum BuChE activity had below the normal level of erythrocyte AChE. Figure 2 shows that a decrease in erythrocyte AChE activity was observed when serum BuChE activity was severely depressed. Human plasma ChE is more sensitive to inhibition than $\mathrm{AChE}$ such as brain $\mathrm{AChE}^{1)}$. It has been suggested that the decrease in erythrocyte AChE follows severe and continuous depression of serum $\mathrm{ChE}$. Chen et al. reported that erythrocyte AChE activity was 12 - to 14-fold more sensitive as an indicator of chlorpyrifos exposure than $\mathrm{AChE}$ in the most sensitive relevant neurological tissues, and that inhibition was an appropriate surrogate measure of chlorpyrifos exposure ${ }^{20)}$. Nevertheless, we showed that sensory nerve conduction velocity in the sural nerve was significantly reduced in both legs in all 6 workers in spite of slight depression of erythrocyte AChE activities or in the normal range. Therefore, serum BuChE activity is more useful than erythrocyte AChE activity in assessing the exposure level and the effects of chlorpyrifos on health.

Blood chlorpyrifos concentrations were $2-8 \mathrm{ng} / \mathrm{ml}$ in 4 workers whose serum BuChE activities ranged from 0.01 to $0.03 \Delta \mathrm{pH}$. They had sprayed chlorpyrifos for 5 
to 6 working days before the blood sampling. The detection of organophosphate pesticides in the blood is difficult because it is metabolized rapidly, but one can detect traces of organophosphate pesticide only when sprayed repeatedly during the busy season. From medical examinations conducted in the busy season, we could detect trace level of chlorpyrifos or fenitrothion in the blood of 27 of 55 workers who sprayed until the day before the examination, 6 of 16 workers who sprayed until $2 \mathrm{~d}$ before the examination and no trace levels in 15 workers until 3 d before (unpublished data). Fournier et al. showed that the identification of organophosphate pesticides in the blood is difficult beyond $48 \mathrm{~h}$ after exposure $^{22}$. Fenitrothion residues in the serum of apple orchard applicators were $13-20 \mathrm{ng} / \mathrm{ml}$ after spraying, but were not detected the next morning ${ }^{23\}}$. Sunaga $e t$ al. showed that the blood chlorpyrifos concentration $(0.93$ nmole $/ l$ ) the next morning was $1 / 7$ of that $(6.6 \mathrm{nmole} / l)$ immediately after spraying ${ }^{5}$. Asakawa et al. also showed that the plasma chlorpyrifos concentrations of 2 TCOs were 0.87 and $4.73 \mathrm{ng} / \mathrm{g}$ postwork ${ }^{6}$. Therefore, the weak depression of erythrocyte $\mathrm{AChE}$ and the detection of chlorpyrifos in the blood is a possible sign of severe exposure to chlorpyrifos.

Savage et al. ${ }^{23 j}$ and Engel et al. ${ }^{243}$ reported that workers exposed to low levels of organophosphate did not show significant neurophysiological differences. Misra et al. showed significantly $(\mathrm{p}<0.01)$ reduced motor conduction velocities and prolonged terminal motor latencies in the peroneal nerves of workers exposed to fenthion for a mean duration of $8.5 \mathrm{yr}^{25}$. Their plasma ChE activity levels were depressed, but there was no clinical evidence of neuropathy, as in our results. Kaplan et al. reported peripheral neuropathy and CNS dysfunction in 8 workers exposed to chlorpyrifos, and they concluded that chlorpyrifos should be used with caution ${ }^{26}$. Therefore, the measurement of peripheral nerve conduction velocity, especially sensory nerve conduction velocity in the sural nerve, may be useful for assessing the effects of exposure to chlorpyrifos on human health.

Engel et al. reported that a change in EEGs was observed on severe acute poisoning by organophosphate pesticide $^{24 !}$. In our survey, we could not find this change. It is possible that the workers had no typical signs and symptoms of acute poisoning due to chlorpyrifos.

In the ophthalmic examinations, the accommodation time for 4 of 6 workers was over the normal range, and the electroretinography (ERG) results for 2 of 6 workers were abnormal. Yoshikawa et al. found that ERG caused a $50 \%$ decrease in the $\mathrm{A}$ or $\mathrm{B}$ wave after injecting 0.05 $\mathrm{mmol}(18 \mathrm{mg}) / \mathrm{kg}$ chlorpyrifos intraperitoneally ${ }^{27)}$. They also surveyed 8 pest and termite operators, and detected urinary metabolite diethyl phosphate and ERG changes in one operator who had low plasma and erythrocyte $\mathrm{ChE}$ activities $^{28}$. In our survey, similar abnormal ERG was observed in 2 of 6 workers who had severely depressed serum BuChE levels. Therefore, the abnormal ERG might be due to severe exposure to chlorpyrifos.

In summary, our medical examination of termite control operators showed adverse health effects such as severe depression of serum BuChE activity, reduction of sensory nerve conduction velocity, and remarkable disappearance of ERG resulting from repeated exposure to chlorpyrifos. Depression of erythrocyte AChE activity was accompanied by severe depression of serum BuChE activity, but they had no obvious subjective symptoms of poisoning by organophosphate. Therefore, periodical medical checkups are needed to protect the health of these workers. The measurements of peripheral nerve conduction velocity, ERG, and accommodation time may possibly be useful as well as that of serum BuChE activity.

\section{References}

1) Smegal DC. Human Health Risk Assessment Chlorpyrifos. Office of Pesticide Programs, U.S.EPA, Washington DC. 2000: 1-25.

2) Miyazaki T, Akiyama K, Kaneko S, Horii S, Yamagishi T. Identification of chlordanes and related compounds in goby-fish from Tokyo Bay. Bull Environ Contam Toxicol 1980; 24: 1-8.

3) Saito I, Kawamura N, Uno K, et al. Relationship between chlordane and its metabolites in blood of pest control operators and spraying conditions. Int Arch Occup Environ Health 1986; 58: 91-97.

4) Sunaga $M$, Yoshida $M$, Ueda $T$, et al. Urinary alkylphosphate levels as an index of exposure to organophosphorus insecticides in pest control operators. Jpn J Hyg (Nippon Eiseigaku Zasshi) 1989; 44: 763-770.

5) Sunaga M, Yoshida M, Ueda T, Kosaka M, Hara I. Relationship between exposure to chlorpyrifos and concentration of urinary alkylphosphates in termite control workers. Jpn J Ind Health (Sangyo Igaku) 1989; 31: 142-149.

6) Asakawa F, Jitsunari F, Suna $S$, et al. The actual state of occupational exposure to chlorpyrifos of termite control workers. Jpn J Hyg (Nippon Eiseigaku Zasshi) 1989; 44: 921-928.

7) Jitsunari F, Asakawa F, Nakajima T, Shimada J, Ogata M. Determination of 3,5,6-trichloro-2-pyridinol levels in the urine of termite control workers using chlorpyrifos. Acta Med Okayama 1989; 43: 299-306.

8) Jitsunari F, Asakawa $F$, Shiraishi $H$, et al. Variations in blood cholinesterase activity and exposure to chlorpyrifos in termite-control workers. Jpn J Hyg (Nippon Eiseigaku Zasshi) 1990; 44: 1049-1058.

9) Ueda T, Kosaka M, Yoshida M, et al. Health effects and personal protection in pest control workers using organophosphorus insecticides. Nippon Koshu Eisei Zasshi 1992; 39: 147-152.

10) Davis DL, Ahmed AK. Exposures from indoor spraying of chlorpyrifos pose greater health risks to children than currently estimated. Environ Health Perspect 
1998; 106: 299-301.

11) Sherman JD. Chlorpyrifos (Dursban)-associated birth defects: report of four cases. Arch Environ Health 1996; $51 ; 5-8$.

12) Thrasher JD, Madison R, Broughton A. Immunologic abnormalities in humans exposed to chlorpyrifos: preliminary observations. Arch Environ Health 1993; 48: 89-93.

13) U.S. EPA Headquarters Press Release, Washington DC. June 8, 2000.

14) Takahashi H, Shibata S. A simple method for the serum cholinesterase determination applicable to routine examination. Medicine and Biology (Igaku To Seibutsugaku) 1951; 20:96-98.

15) Voss G, Sachsse K. Red cell and plasma cholinesterase activities in microsamples of human and animal blood determined simultaneously by a modified acetylthiocholine/DTNB procedure. Toxicol Appl Pharmacol 1970; 16: 764-772.

16) Gamo M, Oka T, Nakanishi J. A method evaluating population risks from chemical exposure: A case study concerning prohibition of chlordane use in Japan. Regul Toxicol Pharmcol, 1995; 21: 151-157.

17) ACGIH: Threshold limit values and biological exposure indices for 1987-1988 Cincinnati:ACGIH 1987: 51-64.

18) Nolan RJ, Rick DL, Freshour NL, Saunders JH. Chlorpyrifos: Pharmacokinetics in human volunteers. Toxicol Appl Pharmcol 1984; 73: 8-15.

19) Griffin P, Mason H, Heywood K, Cocher J. Oral and dermal absorption of chlorpyrifos: a human volunteer study. Occup Environ Med 1999; 56: 10-13.

20) Chen WL, Sheets JJ, Nolan RJ, Mattsson JL. Human red blood cell acetylcholinesterase inhibition as the appropriate and conservative surrogate endpoint for establishing chlorpyrifos reference dose. Regul Toxicol Pharmacol 1999; 29: 15-22.

21) WHO: Environmental Health Criteria 63 , Organophosphorus Insecticides: A General Introduction 1986: 97-111.

22) Fournier E, Sonnier M, Dally S. Detection and assay of organophosphate pesticides in human blood by gas chromatography. Clin Toxicol 1978; 12: 457-462.

23) Savage EP, Keefe TJ, Mounce LM, Heaton RK, Lewis JA, Burcar PJ. Chronic neurological sequelae of acute organophosphate pesticide poisoning. Arch Envioron Health 1988; 43: 38-45.

24) Engel LS, Keifer MC, Checkoway H, Robinson LR, Vaughan TL. Neurophysiological function in farm workers exposed to organophosphate pesticides. Arch Environ Health 1998; 53: 7-14.

25) Misra UK, Nag D, Khan WA, Ray PK. A study of nerve conduction velocity, late responses and neuromuscular synapse functions in organophosphate workers in India. Arch Toxicol 1988; 61: 496-500.

26) Kaplan JG, Kessler J, Rosenberg N, Pack D, Schaumburg HH. Sensory neuropathy associated with Dursban (chlorpyrifos) exposure. Neurology 1993; 43: 2193-2196.

27) Yoshikawa H, Yoshida M, Hara I. Effect of administration with chlorpyrifos on electroretinogram in rats. Jpn J Hyg (Nippon Eiseigaku Zasshi) 1990; 45: 884-889.

28) Yoshikawa H, Yoshida M, Ueda T, Yatsugi K, Hara I. Evaluation of exposure to organophosphorus insecticides and its effect on ocular function in pest control operators. Jpn J Toxicol (Chudoku Kenkyu) 1991; 4: 65-71. 